\title{
The Development of E-Book Learning Media on Bilingual Learning Course
}

\author{
Dody Feliks Pandimun Ambarita ${ }^{1}$, Naeklan Simbolon ${ }^{2}$, Eva Betty Simanjuntak ${ }^{3}$, and \\ Andri Kristianto Sitanggang ${ }^{4 *}$
}

1,2,3,4 Department of Primary School Teacher Education, Faculty of Science Education, Universitas Negeri Medan, Jl. Willem Iskandar Pasar V Medan Estate, Medan Tembung 20221, Indonesia

*Corresponding email: dodyambarita@unimed.ac.id

\begin{abstract}
The purposes of this study are to know the development and feasibility of e-book learning media on Bilingual Learning Course. This study is a research and development and use ADDIE model, namely analysis, design, development, implementation and evaluation. Regarding product validity, researchers ask experts who really understand and even master their fields. Material expert gives a value of 4.4 and categorized as very good. For the media, media expert gives an assessment of 4.45 and considered very good.
\end{abstract}

Keywords: E-book, Media, Bilingual learning.

\section{INTRODUCTION}

Education in Law Number 20 Year 2003 is a conscious and planned effort to create a learning atmosphere and learning process so that students actively develop their potential to have religious spiritual strength, self-control, personality, intelligence, noble character, and the skills they need, society, nation and state [1]. Therefore, the efforts that can be made to achieve the definition of education can be pursued through a good and planned educational process. The educational process according to Regulation of the Minister of Education and Culture Number 59 Year 2014 is a process that provides opportunities for students to develop their potential into rational thinking skills and academic brilliance by giving meaning to what they see, hear, read, and learn to apply in everyday life [2]. However, based on observation on Bilingual Learning course at Primary School Teacher Education, Faculty of Science Education, Universitas Negeri Medan which has been taught, it was found that Bilingual Learning is dominated by power point learning media so that college students feel bored and less enthusiastic when learning takes place which causes the learning process to be ineffective and learning objectives are not achieved.

For this reason, the development of students' selfpotential, the use of innovative, varied, interesting, contextual learning media and according to the level of student needs to be held. With this learning media, it can trigger a fun learning process, so that an effective learning process will be created and learning objectives can be achieved. According to Hamidjojo (in Azhar, 2003:4) that media are all forms of intermediaries used by humans to convey or spread ideas, thought or opinions so that the ideas, thought or opinions expressed reach the recipient properly [3]. Meanwhile, Miarso (2011:458) that learning media are everything that is used to channel messages and can stimulate the thoughts, feelings, attention, and willingness of students so that it can encourage a deliberate, purposeful, and controlled learning process [4]. Therefore, the development of learning media needs to be carried out at Primary School Teacher Education, Faculty of Science Education, Universitas Negeri Medan on Bilingual Learning course. One of the optimization efforts that can be done by lecturers is to hold an e-book that is packaged in an attractive way.

Based on the background of the study described above, The problem in this research are how is the development and feasibility of e-book learning media on Bilingual Learning course? The purposes of this study are to determine the form and feasibility of e-book learning media on Bilingual Learning course.

\section{METHODS}

This is a research and development (R\&D), which is a type of research that aims to produce certain product and test the quality of that product [5]. The product that 
will be produced is an e-book learning media on the Bilingual Learning course. The development model used in this study is ADDIE model, namely: (1) Analysis, (2) Design, (3) Development, (4) Implementation, and (5) Evaluation. In this study, only to development stage was carried out but implementation and evaluation stage was not carried out due and time constraint.

The instruments in this study were observation and validation sheets. Observation was made to determine the character of college students and the technology used so that the product developed was in accordance with the results of this observation. Meanwhile, validation sheets were used to collect data on material expert validation and media expert validation regarding the product being developed. This research uses descriptive analysis techniques to analyze data by describing the data that has been collected from the results of development and validator responses to obtain the form and feasibility of e-book.

\section{RESULTS}

\subsection{Analysis}

This development begins by analyzing some of necessary requirements. Some of necessary requirements include: (1) library research and field study and (2) needs analysis. Library research and field study aim to obtain information about how the learning process for Bilingual Learning course that usually takes place, includes methods commonly used by lecturers, what media are commonly used, how students learn outcomes, and what obstacles are experienced during learning take place. In addition, at this stage also looking for information related to the material raised and developed into learning media, including reviewing theories obtained through books, journals, and studies of research results that are relevant to the development of e-book learning media. Needs analysis includes curriculum analysis, characteristics of Bilingual Learning course, student characteristics, and selection of software for developing e-book.

\subsection{Design}

At this stage, there are several activities carried out such as: (1) establish basic competencies and learning objectives and (2) designing learning media. The determination of basic competencies and learning objectives that will be developed in e-book media is the result of discussions and various considerations with Bilingual Learning course lecturers. Designing learning media is carried out by making an overview and design of an e-book for Bilingual Learning course that will be developed. This stage includes the design of display as well as the material that will be displayed in e-book media including the selection of introductory images, supporting videos and exercises that are in accordance with the material and purpose of making e-book.

\subsection{Development Stage}

At this stage, there are 2 activities carried out, namely: (1) media production and (2) product validation. The production of e-book learning media adapted to designs that have been made previously. The e-book was created using Kvisoft Flipbook Maker application by including images and videos to support the learning. The material displayed is a summary of the material on the chosen topic so that it is easier for users to understand. The product validation consists of two validation stages, namely material validation and media validation. Material validation is carried out by material experts, the aim is to get an assessment from material expert regarding to the material presented. Meanwhile, media validation is carried out by media expert with the aim of getting an assessment from media experts regarding the developed media. The data was obtained through validation sheets given to the experts. The data obtained from each expert is collected and then processed into quantitative data, then the average data is sought. The average result determines the quality of the developed e-book. Suggestions and inputs from each expert are used as a guideline to make revisions or improvements to the developed e-book learning media.

Table 1. The results of material expert

\begin{tabular}{ccc}
\hline $\begin{array}{c}\text { Assessment } \\
\text { Aspect }\end{array}$ & Average & Category \\
\hline Contents & 4.4 & Very good \\
Learning & 4.4 & Very good \\
Total Average & $\mathbf{4 . 4}$ & Very good \\
\hline
\end{tabular}

Based on the table, it shows that the assessment of the material expert related to the content aspect obtained an average score of 4.4 which is included in the very good category, the assessment of the material expert related to the learning aspect obtained an average score of 4.4 which is included in the very good category and based on the assessment of the material expert related to content aspect and learning aspect obtained an average score of 4.4 which is included in the very good category.

Table 2. The results of media expert

\begin{tabular}{ccc}
\hline Assessment Aspect & Average & Category \\
\hline Appereance & 4.5 & Very good \\
Media Elements & 4.33 & Very good \\
Grammar & 4.5 & Very good \\
Total Average & $\mathbf{4 . 4 5}$ & Very good \\
\hline
\end{tabular}

Based on the table, it shows that the assessment of the media expert related to the appereance aspect obtained an average score of 4.5 which is included in the very good category, the assessment of the media expert related to the media elements aspect obtained an average score of 4.33 which is included in the very good category, the assessment of the media expert related to the grammar aspect obtained an average score of 4.5 
which is included in the very good category and based on the assessment of the material expert related to appereance aspect, media elements aspect and grammar aspect obtained an average score of 4.45 which is included in the very good category.

\section{DISCUSSION}

The developed e-book learning media has met the valid word. The fulfillment of a good validity aspect is in line with the opinion expressed by Amri (2013:207) which states that the validity aspect refers to the extent to which the device design is developed [6]. The e-book learning media developed has gone through a validation process by the validator. The feasibility test of e-book media can be seen from the validation results of material expert and media expert, where the average validation result from material expert is 4.4 included in the very good category and media expert is 4.45 included in the very good category.

\section{CONCLUSION}

This research was conducted through several stages, namely: (1) analysis, (2) design, (3) development. Analysis stage includes library research and field study and needs analysis. Design stage includes establish course learning achievement, indicator of course learning achievement, learning materials and designing learning media. Development stage includes media production and product validation. Regarding to the product feasibiliy, the results of validation data from material validation obtained an average of 4.4 included in the very good category and media experts obtained an average of 4.45 included in the very good category.

\section{REFERENCES}

[1] Depdikbud. 2003. Undang-Undang RI Nomor 20 Tahun 2003, tentang Sistem Pendidikan Nasional.

[2] Kemendikbud. 2014. Permendikbud Nomor 59 Tahun 2014 Tentang Kurikulum 2013 Sekolah Menengah Atas/Madrasah Aliyah. Jakarta: Kemendikbud.

[3] Azhar, Arsyad. 2003. Media Pembelajaran. Jakarta: PT Raja Grafindo.

[4] Miarso, Yusufhadi. 2011. Menyemai Benih Teknologi Pendidikan. Jakarta: Kencana Prenada Media Group.

[5] Sugiyono. 2013. Metode Penelitian Kuantitatif, Kualitatif, dan R\&D. Bandung: Alfabeta.

[6] Amri, Sofia. 2013. Development \& Learning Models in the 2013 Curriculum. Jakarta: PT. Library Achievement. 